Egypt. J. of Nutrition and Health Vol. 16 No. 1January (2021)

\title{
Prophylactic Effect of Spirulina Versus Monosodium Glutamate Induced Thyroid Disorders in Experimental Rats
}

\author{
Amira L. Abd Allah \\ Nutrition and Food Science Dept., Faculty of Home Economics, Al- Azhar University
}

\begin{abstract}
Monosodium glutamate (MSG) is one of the most extensively used food additives worldwide, which is ingested as part of commercially processed foods. This study aimed to investigate the protective effects of Spirulina (sp) on MSG-induced thyroid disorders in rats. Thirty male albino rats $(170 \pm 10 \mathrm{~g})$ were used in this expeiment. The rats were divided into 5 groups (6 rats in each group), control group (G1), MSG group (G2): treated with MSG (60 mg/k g b.wt./ day), MSG+ 0.5\% Sp group (G3), MSG+ $1 \% \mathrm{Sp}$ group (G4), and MSG+2\% Sp group (G5). The experiment continued for 28 days. Thyroid gland was examined using biological, biochemical, and histological tests. HPLC analysis of phenolic compounds and chemical composition of Spirulina demonstrated that Spirulina can be considered as a good source of protein, carbohydrates, fibers, minerals (such as iodine), phenolic acids (such as pyrogallol), chlorogenic, catechein and ellagic. In the MSG + SP groups, the biological results indicated that a significant decline in body weight gain (BWG \%) and feed intake (FI) were exhibited. Biochemically, a significant decrease in thyroid-stimulating hormone (TSH) and a significant increase in Triiodothyronine (T3) and thyroxine (T4) hormone levels were marketed. As well, a significant increase of antioxidant markers catalase (CAT), glutathione peroxidase (GPX) was noticed in addition to reduced glutathione (GSH) and a decrease in malondialdehyde (MDA) content in thyroid tissues. Histopathological examination of thyroid gland supported these findings and revealed a marked lesion. Therefore, this study reveals that Spirulina may alleviate MSG-induced thyroid disorders and play a significant role in the regulation of thyroid hormones in rats.
\end{abstract}

Key words: Thyroid hormones, Phenolic acids, Glutathione peroxidase, Thyroxine

\section{Introduction}

Monosodium Glutamate (MSG) is a water-soluble salt of glutamic acid, a non-essential amino acid, normally synthesized in the body and prevalent in protein foods. MSG is utilized world-wide for its "umami" taste and flavor enhancement qualities; the human body does not discriminate between glutamate present in food and that added as seasoning (Henry-Unaeze, 2017).However, MSG is one of the world's most extensively used food additives which are ingested as part of commercially processed foods. MSG is a slow excitotoxin food additive which can cause generation of numerous amounts of free radicals which affects many organs such as thyroid gland (Hassan, et al., 2020). The usage of medicinal plants and their natural products as a therapy against MSG used in food industry has been suggested to be protective (Hajihasaniet al., 2020).

The thyroid gland is one of the important endocrine glands that play an essential vital role in the metabolism and energy expense in the body (Stathatos, 2019). This gland is responsible for production, storage, and releasing of the thyroid hormones;triiodothyronine (T3) and thyroxine (T4) 


\section{Amira L. Abd Allah}

(Rajab et al., 2017). Thyroid hormones (TH) regulate essential metabolic process to a normal growth and development, they also regulate the organism metabolism, correlating the body weight and the expenditure of energy (Gnocchi et al., 2016). Environmental and nutritional factors are often implicated in the occurrence of most thyroid disorders that occur in the most part of the world (Abid et al., 2016). Hypothyroidism is a decrease in the production of the thyroid hormones and leads to gland dysfunction (EL-Tantawi and Abozeid, 2019). Hypothyroidism characterizes the reduction of energy liberation, weight gain, increase of cholesterol levels, reduction of lipolysis and gluconeogenesis (Brent, 2012).

Spirulina, a cyanobacteria commonly referred to as a blue-green algae, is one of the oldest life forms on Earth. Spirulina grows in both fresh and saltwater sources and is known for its high protein and micronutrient content, it has been widely used in several countries, it is considered GRAS (generally recognized as safe), without toxicological effects, and it is approved by the FDA (U.S.A.) and the Brazillian Health Surveillance Agency (Agencia Nacional de Vigilancia Sanitaria - ANVISA) (Navacchi et al., 2012 and DiNicolantonio et al., 2020).Rich in protein (up to 65\%), spirulina is considered safe for consumption by humans and animals, and it has been cultivated and used as a food source worldwide (Sharoba, 2014). Also, this alga is a rich source of phycocyanin, carotenoids, biliprotein pigment, proteins, phenolic acids, iodine, and vitamins (Anahite et al., 2018). Hence SP is considered an excellent nutritional supplement with many health benefits, it is rich in protein, carotenoid ( $\beta$-carotene), polyunsaturated fatty acids, glycolipids, polysaccharides, vitamins $A, E, B$, iodine, calcium, magnesium, manganese, potassium, zinc, and iron (Hoseini et al., 2013). Due to such biological properties about Spirulina and its high content of phenolic compounds and iodine, the current study was designed to examine for the protective and ameliorative potential of this alga against the thyroid disorders induced by MSG in rats.

\section{Materials and methods}

Spirulina platensis powder was obtained from Biotechnology Unit, National Research Centre (NRC), Egypt. Casein, minerals, vitamins, and cellulose were obtained from EL-Gomhoryia (Chemicals Company), Tanta, Egypt.Thirty male albino rats (Sprague Dawely Strain) were purchased from the Vaccine and Immunity Organization, Helwan Farm, Cairo, Egypt.

\section{Analysis of Spirulina Chemical composition}

Spirulina was chemically analyzed for moisture, fat, crude protein, crude fiber, and ash, according to methods of (A.O.A.C., 2000). Total carbohydrate was calculated by difference using the following equation:

Total carbohydrate $=100-(\%$ moisture $+\%$ fat $+\%$ ash $+\%$ crude fibers $+\%$ protein $)$

\section{lodine content}

lodine content was determined according to the method described by Kirkbright et al., (1974)using Atomic absorption spectroscopy.

\section{Fractionation and identification of phenolic compounds}

Phenolic compounds were determined by HPLC, fractionated and identificated according to the method of Goupy et al., (1999). 


\section{Egypt. J. of Nutrition and Health Vol. 16 No. 1January (2021)}

\section{Diet composition and experimental animal design}

Basal Diet:

Basal diet was prepared from fine ingredients per $100 \mathrm{~g}$ according to(Reeves et al.1993), and water supply was given ad-libitum and checked daily.

\section{Experimental design}

Thirty male albino rats of Sprague Dawely strain weighing an average of (170 $\pm 10 \mathrm{~g})$ were used in the study and obtained from Vaccine and Immunity Organization, Helwan Farm, Cairo, Egypt. After the adaptation period of seven days, the animals were divided into five equal groups ( 6 rats each) as follows:

Control group (G1): untreated group and fed on basal diet.

MSG group (G2): was fed on basal diet and treated orally with MSG (60 mg/k g b.wt./ day).

MSG+ 0.5\%Sp group(G3): was fed on basal diet supplemented with $0.5 \%$ Spirulina and treated orally with MSG (60 mg/k g b.wt./ day).

MSG+ 1\%Sp group (G4): was fed on basal diet supplemented with $1 \%$ Spirulina and treated orally with MSG (60 mg/k g b.wt./ day).

MSG+ 2\%Sp group (G5): was fed on basal diet supplemented with $2 \%$ Spirulina and treated orally with MSG (60 mg/k g b.wt./ day).

The chosen dose of MSG was built on the harmfulness levels described by previous studies Hassan, et al., (2020), and the doses of Spirulina were selected from published literature according to Mridha et al., (2010).

\section{Biological evaluation}

During the experimental period, the quantities of diet consumed and/or wasted were recorded daily. Additionally, the rat's weight was noted weekly. Feed intake (FI), body weight gain \% (BWG) and feed efficiency ratio (FER) were calculated at the end of the experiment according to the following equations as mentioned by Chapman et al.,(1959).

$\mathrm{FI}=$ Initial diet weight $(\mathrm{g})-$ left over diet weight $(\mathrm{g})$

BWG\%= Final weight $(\mathrm{g})-$ initial weight $(\mathrm{g}) /$ Initial weight $(\mathrm{g}) \times 100$

FER $=$ Weight gain $(g) /$ Feed intake $(g)$

\section{Biochemical analysis}

At the end of the experiment (after $24 \mathrm{hr}$. of the last administration) rats were fasted overnight prior to sacrificing under ether anesthesia. Blood samples were collected from the hepatic portal vein from each rat, to separate the serum for biochemical assays. The thyroid glands were quickly excised and homogenized for used to determine the activities of GPx, CAT, GSH and MDA content and histological examination. The analysis was performed at the Medical College Laboratory, El-Zgazig University, Egypt. Serum was carefully separated into dry, clean Wasserman tubes using a Pasteur pipette and then kept frozen at $-20^{\circ} \mathrm{C}$ till analysis.

\section{Biochemical analyses of thyroid hormones:}

Triiodothyronine (T3), thyroxine (T4) and thyroid-stimulating hormone (TSH) were estimated in the serum according to the method described by López-Torres et al.,(2000)

\section{Assessment of oxidative stress in thyroid tissues}

Lipid peroxidation was assayed in thyroid homogenates by measurement of malondialdehyde (MDA) formation according to the method of Uchiyama and Mihara (1978). 


\section{Amira L. Abd Allah}

Assessment of antioxidant enzymes in thyroid tissues

Activities of catalase (CAT) was determined according to the methods of Sinha (1972);Minami and Yoshikawa (1979), respectively. The reduced glutathione (GSH) content was estimated using a colorimetric technique, as mentioned by Weckbeker and Corey (1988), while the glutathione peroxidase (GPx) activity was measured following the methd of Flohe and Gunzler (1984).

\section{Histopathology Examinations}

Thyroid gland samples were fixed in $10 \%$ formalin solution at room temperature for $24 \mathrm{~h}$. Samples were then dehydrated in ascending grades of ethyl alcohol, cleared in terpineol and embedded in paraffin wax. Paraffin sections $5 \mu \mathrm{m}$ thick were stained with Hematoxylin and Eosin. Photomicrographs were taken using a camera attached to a Leica DM LS2 microscope (Leica Microsystems, Wetzlar, Germany).

\section{Statistical analysis}

Statistical analysis was performed using the program of Statistical Package for the Social Sciences software (SPSS) version 18. The results were expressed as mean \pm Standard deviation (mean \pm S.D.). Data were analyzed using one-way ANOVA (Snedecor and Cochran, 1979).

\section{Results and Discussion}

\section{Chemical composition}

Spirulina was analyzed for their chemical composition (moisture, protein, carbohydrates, fat, crude fiber and ash). The obtained results are shown in table (1), it could be noticed that the protein content in Spirulina accounting for about $55.61 \%$ of algae's dry weight. Also, Spirulina's content of carbohydrate, ash, fiber, fat and moisture representing 20.12, 6.47, 7.10, 5.63 and 5.07\% respectively, while the lodine content is $132 \mathrm{mcg} / 100 \mathrm{~g}$. This is in line with previous findings by Hoseiniet al., (2013)who revealed that Spirulina is characterized by high nutritional value as high protein content (60-70\% by dry weight), vitamins, amino acids, gamma-linoleic acid, vitamins, iron, calcium, magnesium, zinc and iodine. Also, Li et al., (2006) and Sharoba, (2014) found that Spirulina contains $62.84 \%$ protein, higher than any other natural food and an exceptional proportion since the vast majority of plant-based foods (even the ones that are known to be "good protein sources") contain only about $35 \%$. Spirulina contains all the essential amino acids in fairly high amounts. Additionally, Gutiérrez-Salmeán et al., (2015) mentioned that the Spirulina contain a significant amount of proteins (60 to $70 \%$ ), total carbohydrate $17.8 \mathrm{~g} / 100 \mathrm{mg}$, fiber $(7.7 \mathrm{~g} / 100 \mathrm{mg})$ and iodine $(142 \mathrm{mcg} / 100 \mathrm{~g})$. Likewise, El-Chaghaby et al., (2019) who found that the proximate analysis results indicated high values of protein for Spirulina platensis (53.30 \% dry wt.) whereas the highest fat, ash and moisture percentages were recorded by Scenedesmus obliquus (15.13, 15.07 and 2.57, respectively). 
Egypt. J. of Nutrition and Health Vol. 16 No. 1January (2021)

Table (1)

Spirulina chemical composition of value per $100 \mathrm{~g}$ dry weight

\begin{tabular}{l|l}
\hline Parameter & Amount \\
\hline Dry matter & $94.93 \mathrm{~g}$ \\
\hline Moisture & $5.07 \mathrm{~g}$ \\
\hline Crude protein & $55.61 \mathrm{~g}$ \\
\hline Crude fat & $5.63 \mathrm{~g}$ \\
\hline Fiber & $7.10 \mathrm{~g}$ \\
\hline Ash & $6.47 \mathrm{~g}$ \\
\hline Carbohydrates & $20.12 \mathrm{~g}$ \\
\hline lodine & $132 \mathrm{mcg}$ \\
\hline
\end{tabular}

Phenolic compounds of Spirulina (ppm.) by HPLC analysis

The main phenolic compounds identified in Spirulina are presented in Table (2). Results show that the predominant phenolic compounds in Spirulina were pyrogallol, chlorogenic, catechein and ellagic (586.93, 87.33, 36.16 and 32.94 ppm, respectively). This finding is supported by the results of earlier studies, which reported that Spirulina is a good source of many phytochemicals such as carotenoids, polyphenols, and phycocyanin (Lu et al., 2006 and El-Desouki et al., 2015). Also, Anahite et al., (2018) who mentioned Spirulina is a rich source of phycocyanin, carotenoids and phenolic acids.

Table (2)

Phenolic compounds of Spirulina (ppm.)

\begin{tabular}{l|c}
\hline Phenolic compounds & Test results of phenolic compounds (ppm) \\
\hline Pyrogallol & 586.93 \\
\hline Chlorogenic & 87.33 \\
\hline Catechein & 36.16 \\
\hline Ellagic & 32.94 \\
\hline Salicylic & 7.93 \\
\hline P-OH-benzoic & 6.98 \\
\hline Caffeine & 6.26 \\
\hline Gallic & 4.92 \\
\hline Catechol & 4.50 \\
\hline Ferulic & 4.09 \\
\hline 4-Aminobenzoic & 3.74 \\
\hline Vanillic & 3.12 \\
\hline Caffeic & 2.53 \\
\hline Coumarin & 2.49 \\
\hline & \\
\hline & \\
\hline
\end{tabular}




\section{Amira L. Abd Allah}

\section{Biological evaluation}

Groups that received MSG revealed a significant increase in the percentage of body weight gain (BWG\%)and feed intake (FI) from control group, while the treatments with the different doses of Spirulina in MSG+ Sp groups (0.5, 1 and $2 \%$ recorded a highly significant decreases in the BWG\% and $\mathrm{FI}$ when compared to the MSG-group alone. As for feed efficiency ratio (FER) the results revealed insignificant changes in all groups. No significant differences were found between groups that consumed the diet supplemented with the different doses of spirulina as shown in table (3). Increased percentage of BWG and FI in MSG-group alone may be due to the palatability of food and disruption of the hypothalamic signaling cascade of leptin action, which cause the link between MSG and obesity and its effect on energy balance (He et al., 2011).These results agreed with Helal et al., (2019) who stated that food additives such as MSG caused increase in body weight when compared to the control group. Similarly, Shukry et al., (2020) found that the MSG causes a significant increase in body weight when administered orally for eight weeks. This increase may be attributed to the fact that MSG can improve foods' palatability by having a favorable effect on the appetite center and enhancing the chemosensory perception (Alalwani, 2014 ;Abd-Ella and Mohamed, 2016 ).

In the present study, Spirulina supplemented diets in MSG+ Sp groups caused a decrease in $\mathrm{FI}$ and BWG\% compared with the MSG group only. This is in line with previous findings by Reyhaneh et al., (2018);EL-Tantawi and Abozeid (2019) who reported that treatment with Spirulina leads to the suppression of body weight gain. This result might be attributed to the decrease in appetite during the experiment. This interpretation is supported by Mazokopakis et al., (2014) who showed that Spirulina is rich in phenylalanine, a potent releaser of cholecystokinin that affects the brain's appetite center, which in turn suppress the body weight.

Table (3)

Protective effect of Spirulina on feed intake, body weight gain\% (BWG \%) and feed efficiency ratio (FER).

\begin{tabular}{|c|c|c|c|}
\hline Parameters & BWG\% & $\mathrm{FI}(\mathrm{g})$ & FER \\
\hline Groups & Mean \pm SD & Mean \pm SD & Mean \pm SD \\
\hline Control group & $29.88^{C} \pm 5.48$ & $655.10^{b} \pm 172.27$ & $0.050^{\mathrm{a}} \pm .003$ \\
\hline MSG group & $89.22^{a} \pm 9.97$ & $846.83^{\mathrm{a}} \pm 165.69$ & $0.090^{\mathrm{a}} \pm 0.070$ \\
\hline $\mathrm{MSG}+0.5 \% \mathrm{Sp}$ groups & $50.46^{b} \pm 7.75$ & $740.72^{\mathrm{ab}} \pm 93.13$ & $0.086^{a} \pm 0.038$ \\
\hline MSG+ $1 \%$ Sp groups & $46.69^{b} \pm 5.65$ & $730.85^{\mathrm{ab}} \pm 92.01$ & $0.087^{a} \pm 0.018$ \\
\hline MSG+ $2 \%$ Sp groups & $54.43^{b} \pm 5.99$ & $735.00^{\mathrm{ab}} \pm 75.35$ & $0.083^{\mathrm{a}} \pm 0.003$ \\
\hline
\end{tabular}

\section{Thyroid hormones}

The results obtained showed a significant increase in serum TSH and a significant decrease in the level of the thyroid hormones T4 and T3 in MSG-group in comparison to control group. Interestingly, the decrease of T3 and T4, also the increase of TSH were significantly lower in the MSG groups treated with Spirulina $(0.5,1$ and $2 \%)$ compared to their relative levels in MSG-group alone. The addition of Spirulina on the diet for rats administrated with MSG $(0.5,1$ and $2 \%)$ showed significant decrease level of serum TSH and significant increase level of T4 and T3 compared to control group.MSG+ $0.5 \% \mathrm{Sp}$ group (G3) revealed the best group for increasing T3 and T4 levels when compared to control group(table 4).

The thyroid gland is an endocrine gland that is responsible for the production, storage, and release of thyroid hormones triiodothyronine (T3) and thyroxin (T4). These hormones are essential for 


\section{Egypt. J. of Nutrition and Health Vol. 16 No. 1January (2021)}

cell growth and development (Vargas-Uricoechea and Anilza 2017). Increase of body weight gain in rats treated with MSG could be attributed to the decline in levels of T3 and T4 that have a potential effect on the metabolism.

In the present study, the administration of MSG caused a decrease in T3 and T4; also, the TSH recorded a significant increase compared to the values in the control group. These results disagreed with the recorded data of Helal et al., (2019) who found that the MSG recorded a highly significant increase in T3 and T4 level $(p<0.01)$, but benzoate recorded a highly significant decrease in T3 and T4 level $(p<0.01)$ as compared to control rats. Still, these results were consistent with the previous findings of Ali et al.,2012 and Sabr (2015) who suggested that loss of thyroid hormones, most probably caused by loss of thyroxin binding globulin along with T4 bound to it, thus stimulating TSH production. Also, Alfallouji et al., (2012) suggests that hypothyroidism syndrome is associated with an overall increase in oxidative stress. Other than the decrease in thyroid function due to oxidative stress, loss of thyroid hormone-binding proteins in urine could be another cause of the decrease in serum T3 and T4 levels. Helal et al.,(2019) showed that this oxidative stress is due to treatment with food additive or its mixtures such as sodium benzoate with MSG.

The findings show a significant decrease level of serum TSH and significant increase level of T4 and T3 in groups feeding on the different doses of Spirulina (0.5, 1 and $2 \%)$ with MSG. These findings are in agreement with EL-Tantawi and Abozeid (2019) who reported that the coadministration of propyl thiouracil (PTU-group) with Spirulina resulted in an insignificant increase in T3 and T4 levels and negligible decrease in the TSH level. Also, Ebrahim (2020) who found that the decrease of T3 and T4 and the increase of TSH were significantly lower $(P<0.05)$ in the irradiated animals treated with Spirulina before irradiation compared to their relative levels in irradiated rats.

Table (4)

Effect of Spirulina on thyroid hormones in MSG-treated rats

\begin{tabular}{|c|c|c|c|}
\hline Parameters & $\mathrm{T} 3 \mathrm{ng} / \mathrm{ml}$ & $\mathrm{T} 4 \mathrm{ng} / \mathrm{dl}$ & TSH ulU/ml \\
\hline Groups & Mean \pm SD & Mean \pm SD & Mean \pm SD \\
\hline Control group & $0.970^{\mathrm{a}} \pm 0.020$ & $3.65^{\mathrm{ab}} \pm 0.458$ & $0.005^{c} \pm .000$ \\
\hline MSG group & $0.470^{C} \pm 0.080$ & $2.27^{\mathrm{C}} \pm 0.586$ & $0.080^{\mathrm{a}} \pm .010$ \\
\hline MSG+ 0.5\% Sp group & $0.573^{\mathrm{b}} \pm 0.025$ & $3.86^{a} \pm 0.544$ & $0.035^{\mathrm{b}} \pm .008$ \\
\hline MSG+ $1 \%$ Sp group & $0.531^{b c} \pm 0.008$ & $2.96^{\mathrm{bc}} \pm 0.098$ & $0.016^{c} \pm .006$ \\
\hline MSG+ $2 \%$ Sp group & $0.533^{b c} \pm 0.025$ & $2.59^{c} \pm 0.362$ & $0.077^{\mathrm{a}} \pm .012$ \\
\hline
\end{tabular}

\section{Thyroid antioxidant status}

The effect of MSG on the antioxidant status of thyroid gland revealed a significant decrease in GSH, GPx and CAT activities. The decrease of antioxidant activity was accompanied by a significant increase in the content of MDA, compared to the control group. Still, Spirulina has significantly ameliorated the MSG-induced oxidative stress in rats fed on diet containing spirulina (MSG+ Sp groups). MSG+ 1\% Sp group (G4) revealed the best group for increasing CAT,GPx and GSH activities, also for decreasing in the content of MDA, compared to the control group. These finding are presented in table (5). This is in line with previous findings by Shukry et al., (2020) who showed that the MSG caused a significant increase in oxidative stress markers malondialdehyde (MDA), reactive oxygen species (ROS) and a significant decrease in superoxide dismutase (SOD), catalase (CAT), glutathione $S$ transferase (GST), and reduced glutathione (GSH). Also, Onobrudu and Nwiloh (2020) revealed 


\section{Amira L. Abd Allah}

that administration of MSG induced imbalance in lipid metabolism, oxidative stress and hepatic dysfunction. These were revealed by significant decreases in CAT and GSH. Additionally, Ebrahim (2020) who found that the Spirulina treatment has significantly attenuated oxidative stress in thyroid tissues. These were revealed by a significant decrease in MDA levels and a significant increases SOD, CAT and glutathione peroxidase (GSH-Px) activities, concomitant with significant amelioration in the levels of thyroid and reproductive hormones.

Table (5)

Effect of Spirulinaon thyroid antioxidant status in MSG-treated rats

\begin{tabular}{|c|c|c|c|c|}
\hline Parameters & CAT $(\mathrm{U} / \mathrm{g})$ & GPX (U/gt) & $\mathrm{GSH} \mathrm{mmol} / \mathrm{gt}$ & MDA nmol/gt \\
\hline Gro & Mean \pm SD & Mean \pm SD & Mean \pm SD & Mean \pm SD \\
\hline Control group & $4.79^{\mathrm{a}} \pm 0.43$ & $470.40^{a} \pm 19.54$ & $1.86^{\mathrm{a}} \pm 0.150$ & $72.83^{\mathrm{C}} \pm 4.06$ \\
\hline MSG group & $0.63^{\mathrm{C}} \pm 0.05$ & $133.97^{e} \pm 5.36$ & $0.44^{\mathrm{d}} \pm 0.072$ & $172.82^{\mathrm{a}} \pm 14.47$ \\
\hline$M S G+0.5 \%$ Sp group & $1.05^{\mathrm{C}} \pm 0.09$ & $213.50^{\mathrm{C}} \pm 11.58$ & $0.78^{\mathrm{bc}} \pm 0.067$ & $142.40^{b} \pm 10.75$ \\
\hline MSG+ $1 \%$ Sp group & $1.60^{b} \pm 0.29$ & $253.20^{b} \pm 16.19$ & $0.92^{\mathrm{b}} \pm 0.047$ & $138.87^{b} \pm 5.95$ \\
\hline MSG+ $2 \%$ Sp group & $0.88^{\mathrm{C}} \pm 0.04$ & $180.95^{\mathrm{d}} \pm 10.45$ & $0.70^{C} \pm 0.010$ & $155.43^{b} \pm 8.35$ \\
\hline
\end{tabular}

\section{Histological results}

Microscopic pictures of hematoxylin and eosin (H\&E) stained thyroid gland sections of the control group (Fig. 1) showing well-formed, tightly packed follicles separated by narrow interfollicular tissue, which contains connective tissues with blood capillaries and clusters of interfollicular cells rounded follicles showing the follicles $(F)$. The follicles are of various sizes and tend to be larger towards periphery. The follicles are lined by simple low cuboidal cells (black arrow) with round nuclei. The lumena of the central follicles are filled with homogeneous acidophilic structureless colloid having peripheral minute vacuolation (blue arrows). Low magnification X100 bar 100 and high magnification X400 bar 50 .

Microscopic pictures of $\mathrm{H} \& \mathrm{E}$ stained thyroid gland sections from MSG-treated group showing decreased number of follicles that appear irregular large and small in size with marked reduction in amount of colloid. The follicles lined with cubical epithelium (arrow) having rounded central nuclei as shown in Fig.(2). Sections of thyroid gland from MSG+ 0.5\%Sp group revealing decreased number of small sized follicles (white arrow) with coalescence of other follicles (blue arrow) and hyperplasia of parafollicular cells (black arrows)( Fig. 3). The follicles are lined with columnar foamy epithelium with basal nuclei and their lumena are devoid of colloid.

Similar findings still present in treated groups MSG+ $1 \% S p$ and MSG+ $2 \%$ Sp but with increasing numbers of follicles (Fig. 4 \& 5) (x100 and $\times$ 400). These results are in harmony with $K$ halaf and Arafat (2015) who revealed that increase in follicular epithelial height and decrease in the colloid was detected in all groups treated with MSG; the peripheral follicles were delimited by cubical epithelial cells with rounded central nuclei and the central ones were lined by columnar epithelium. Also, Dhindsa et al., (1981) who found that irregularity in the shape of some cells, reduced amount of colloid in some follicles together with congested stromal blood vessel after a daily intra-peritoneal injection of MSG $4 \mathrm{mg} / \mathrm{g}$ body weight for seven days and the rats examined after one month from the last dose. Still, EL-Tantawi and Abozeid (2019) reported that the co- administration of propyl thiouracil(PTUgroup) with Spirulina resulted a slight improvement in the thyroid histological structure compared to the PTU-group. It could be interpreting that the histopathological changes have resulted from hyperstimulation of TSH in the PTU group, and these changes also slightly improved by the limited 


\section{Egypt. J. of Nutrition and Health Vol. 16 No. 1January (2021)}

decrease in TSH. These slight improvements appeared as a reduction in the congestion of blood capillaries and little restoration of thyroglobulin in the follicles. So, Spirulina cannot ameliorate the impact of PTU completely.

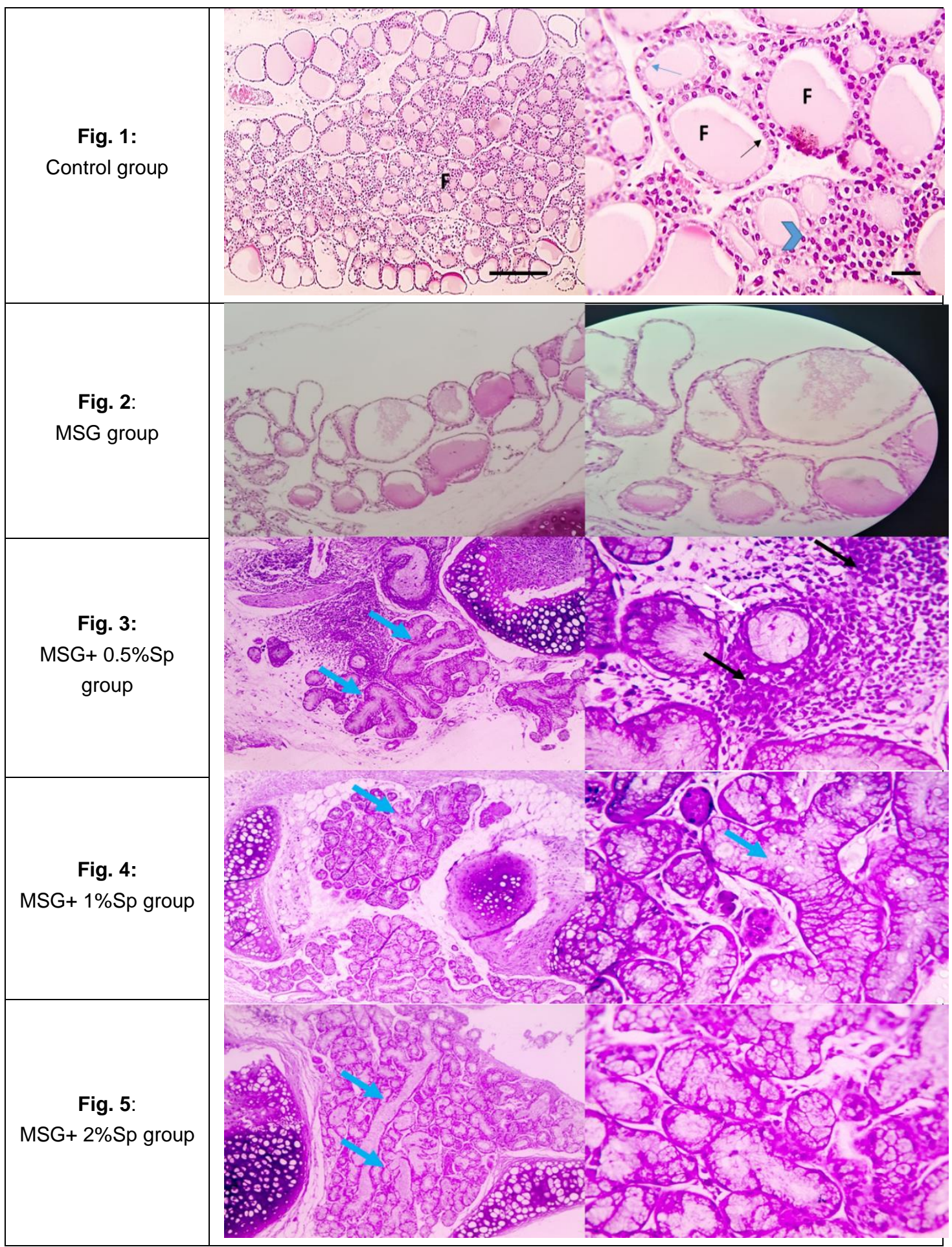




\section{Amira L. Abd Allah}

\section{Conclusion}

It could be concluded that Spirulina is characterized by high nutritional value as high protein content and could be considered as a potential source of natural antioxidants. Thus, the Spirulina supplementation ameliorates the thyroid disorders caused by food additives such as MSG through inhibition of the oxidative stress and reducing lipid peroxidation. The protective effect of Spirulina may be due to the presence of phenolic compounds, which are known by their antioxidant activity. Therefore, the education of the public is needed to increase awareness of the potentially toxic effects of excessive consumption of products containing MSG.

\section{References}

Abd-Ella, E. and Mohamed, A. (2016):

Attenuation of monosodium glutamate-induced hepatic and testicular toxicity in albino rats by Annona muricata Linn. (Annonaceae) leaf extract. J. Pharm. Biol. Sci. 2016, 11, 61-69.

Abid, M.; Sharma, k.; Kumar, K.; Salman, A. S. ;Phool, C. ; Anurag, V. ; Kamal, K. and Khan, N. A. (2016):

Complication and management of hypothyroidism -a review. Indian Journal of Drugs, 2016, 4(2), 42-56 ISSN: 2348-1684.

Alalwani, A.D. (2014):

Monosodium glutamate induced testicular lesions in rats (histological study). Middle East Fertil. Soc. J. 2014, 19, 274-280.

Alfallouji S, Ali R K, Ali W J (2012):

The Correlation between Oxidative Stress and Thyroid Hormones in Serum and Tissue Homogenized of Hypothyroidism Patients. Medical Journal of Babylon, 9 (4): 843-849.

Ali, W. J. H.; Ali, R. K. and Alfallouji, S. (2012):

The Correlation between Oxidative Stress and Thyroid Hormones in Serum and Tissue Homogenized of Hypothyroidism Patients. Medical Journal of Babylon, 9(4): 843-849.

Anahite, O. C.; Carvalho, J. C.; Gilberto Pereira, V. M.; Jacques, P. ,Soccol, V. T. and Soccol, C. R. (2018):

Functional properties and health benefits of bioactive peptides derived from Spirulina: A review." Food reviews international 34.1 (2018): 34-51.

Association of Official Analysis Chemists (AOAC):

International, official methods of analysis. 17th ed. New York, USA: AOAC; 2000.816-51.

Brent, G.A. (2012):

Hypothyroidism and thyroiditis. In: Williams Textbook of Endocrinology, edited by Melmed SP, Larsen PR, and Kronenberg HM. Philadelphia, PA: Elsevier, 2012. 


\section{Egypt. J. of Nutrition and Health Vol. 16 No. 1January (2021)}

Chapman, D.G.; Castilla, R. and Cambell, A.J. (1959):

Evaluation of protein in food. In: Method for the Documentation of protein Efficiency Ratio. Can. J. Biochem. Physiol., 37; 679-686.

Dhindsa, K.S.; Omran, R.G. and Bhup R.(1981):

Histological changes in the thyroid gland induced by monosodium glutamate in mice. ActaAnat (Basel) 1981; 109: 97-102

DiNicolantonio, J. J. ;Bhat , A. G. and OKeefe, J. (2020):

Effects of spirulina on weight loss and blood lipids: a review. Open Heart. 2020; 7(1): e001003.doi: 10.1136/openhrt-2018-001003

Ebrahim, R.M. (2020):

Prophylactic effect of Spirulina platensis on radiation induced thyroid disorders and alteration of reproductive hormones in female albino rats. International Int. J. Radiat. Res., Vol. 18 No. 1, January 2020.

El-Chaghaby, G. A. ;Rashad, S. ;Abdel-Kader, S. F. ; Rawash, E. A. and Abdul Moneem, M. (2019):

Assessment of phytochemical components, proximate composition and antioxidant properties of Scenedesmus obliquus, Chlorella vulgaris and Spirulina platensis algae extracts.

Egyptian Journal of Aquatic Biology \& Fisheries. 23(4): 521 - 526 (2019). ISSN $1110-6131$.

El-Desouki, N.I. G.A.; Tabl, K.K.; Abdel-Aziz, E.I.; Nazeeh, S. N. (2015): Improvement in beta-islets of Langerhans in alloxan-induced diabetic rats by erythropoietin and spirulina, J. Basic Appl. Zool. 71 (2015) 20-31.

EL-Tantawi, H. G. and Abozeid, F. S. (2019):

Impact of Spirulina on Propyl thiouracil - Induced Hypothyroidism in Albino Rats, A Histological, Immunohistochemical and Biochemical Approach. Egyptian Journal of Histology. 42 (4); 849-860. DOI: 10.21608/ejh.2019.16398.1159. ISSN: 1110-0559.

Flohe, L. and Gunzler, W.A. (1984):

Analysis of glutathione peroxidase Methods Enzymol., 105 (1984), pp. 114-121

Gnocchi, D.; Steffensen, K.R.; Bruscalupi, G.; Parini, P. (2016):

Emerging role of thyroid hormone metabolites 217(3):184 -216. doi: 10.1111/apha.12648.

Goupy, P.; Hugues M.; Boivin, P. and Amiot, j. (1999):

Antioxidant composition and activity of barley (Hordeumvulgare) and malt extract and of isolated phenolic compunds. J.Sci. Food Agric.79: 1625-1634.

Gutiérrez-Salmeán, G.; Fabila-Castillo, L. and Chamorro-Cevallos, G. (2015):

Nutritional and toxicological aspects of Spirulina (Arthrospira).Nutr Hosp.:32(1):34-40. 


\section{Amira L. Abd Allah}

Hajihasani, M.M.; Soheili, V.; Zirak, M.R.; Sahebkar, A.H. and Shakeri, A. (2020): Natural products as safeguards against monosodium glutamate-induced toxicity. Iran J Basic Med Sci 2020; 23:416-430. doi: 10.22038/IJBMS. 43060.10123.

Hassan, D. A.; Abdel Alim, M. A.; Sharkawi, S. M.Z.; Nabil, S. (2020):

Detection of cardiac tissues toxicity caused by monosodium glutamate and the protective role of vitamin c by immunohistochemical method, heart tissue oxidative stress biomarkers and cardiac dysfunction biomarkers. Egypt J. Forensic Sci.Appli.Toxicol. 20 (3); 13-21.

He, K.; Du, S. and Xun, P. et al. (2011):

Consumption of Monosodium Glutamate in Relation to Incidence of Overweight in Chinese Adults: China Health and Nutrition Survey (CHNS)". The American Journal of Clinical Nutrition, 93(6): 1328-36.

Helal E. G.E. ; Barayan, A. W.; Abdelaziz, M. A. and EL-Shenawe, N. S.A (2019):

Adverse Effects of Mono Sodium Glutamate, Sodium Benzoate and Chlorophyllins on some Physiological Parameters in Male Albino Rats. The Egyptian Journal of Hospital Medicine. 74 (8):1857-1864.

Henry-Unaeze, H.N. (2017):

Update on food safety of monosodium I-glutamate (MSG). Pathophysiology. 24, (4): 243-249.

Hoseini, S.M.; Khosravi- Darani, K. and Mozafari, M.R. (2013):

Nutritional and medical-applications of Spirulina microalgae. Mini-Reviews in Medicinal Chemistry, 13(8): 1231-1237.

Khalaf. H. A and Arafat, E. A. (2015):

Effect of different doses of monosodium glutamate on the thyroid follicular cells of adult male albino rats: a histological study.Int J ClinExpPathol 2015;8(12):15498-15510.

Kirkbright, G.F. West, T.S. and Wilson, P.J. (1974):

The determination of iodine by atomic absorption and emission spectrometry with a cathode sputtering cell. Analytica Chimica Acta. 68( 2); 462-465. https://doi.org/10.1016/S00032670(01)82603-9.

Li, Z.Y.; Guo, S.Y.; Li, L. et al. (2006):

Effects of electromagnetic field on the batch cultivation of spirulinaplatensisin an air-lift photobioreactor. Bioresour Technol. 98(3): 700-5.

López-Torres, M. ; Maria, R. Barja, G. (2000):

Effect of hormones on mitochondrial oxygen free radical production and DNA oxidative damage in the rat heart Mol. Cell. Endocrinol., 168 (2000), pp. 127-134

Lu, H.K.; Hsieh,C.C.; Hsu, J.J.; Yang,Y.K. Chou, H.N. (2006):

Preventive effects ofSpirulinaplatensison skeletal muscle damage under exercise-induced oxidative stress, Eur. J. Appl. Physiol. 98, 220-226. 


\section{Egypt. J. of Nutrition and Health Vol. 16 No. 1January (2021)}

Mazokopakis, E. E.; Starakis, I.; Papadomanolaki, M. G., Mavroeidi, N. G. and Emmanuel S. (2014):

The hypolipidaemic effects of Spirulina (Arthrospiraplatensis) supplementation in a Cretan population: a prospective study." Journal of the Science of Food and Agriculture, 94(3): 432437.

Minami, M. and Yoshikawa, H. (1979):

A simplified assay method of SOD activity of clinical use. Clin Chem Acta, 92(3): 337-342.

Mridha, M. O. F.; Noor P.; Khaton R.; Islamb, D. and Hossainb M.(2010):

Effect of Spirulina platensis on Lipid Profile of Long Evans Rats. Bangladesh J. Sci. Ind. Res. 45(3), 249-254.

Navacchi, M.F.P.; Monteiro de Carvalho, J. C.; Takeuchi, K. P. and Danesi, E.D.G. (2012):

Development of cassava cake enriched with its own bran and Spirulina platensis. Acta Scientiarum Technology (Maringá), 34(4), 465-472, doi: 10.4025/actascitechnol.v34i4.1068

Onobrudu, D. A. and Nwiloh, B. I. (2020):

Monosodium glutamate alter hepatic functions, redox potential and lipid metabolism: Omega 3 fatty acids ameliorative intervention. GSC Biological and Pharmaceutical Sciences,13(01), $101-110$.

Rajab, N.M.; Mirela Ukropina, A. and Milosevic, M. C. (207):

Histological and ultrastructural alterations of rat thyroid gland after short-term treatment with high doses of thyroid hormones." Saudi journal of biological sciences 24.6 (2017): 1117-1125.

Reeves, P.G.; Nielsen, F.H. and Fahmy, G.C. (1993):

Reported of the Amirican Institute of Nutrition adhoe wriling committee on the reformulation of the AIN- 76A-Rodendeit". J Nutr., 123:1939 -1951.

Reyhaneh, Y.; Saidpour, A. and Mottaghi, A. (2018):

The effects of Spirulina supplementation on metabolic syndrome components, its liver manifestation and related inflammatory markers: A systematic review. Complementary therapies in medicine.42:137-144. DOI: 10.1016/j.ctim. 2018. 11.013.

Sabr, A.N. (2015):

Effect of sodium benzoate in the level of thyroid stimulating hormone and the level of thyroxin hormone in mature albino male rats. Journal of kerbala university, 13 (1): 295-299 .

Sharoba, A. M. (2014):

Nutritional value of spirulina and its use in the preparation of some complementary baby food formulas. Journal of Agroalimentary Processes and Technologies 20(4), 330-350.

Shukry, M.; El-Shehawi, A. M. ; . El-Kholy, W. M ; . Elsisy, R. A ;Hamoda, H. S. et al., (2020): Ameliorative Effect of Graviola (Annonamuricata) on Mono Sodium Glutamate-Induced Hepatic Injury in Rats: Antioxidant, Apoptotic, Anti-inflammatory, Lipogenesis Markers, and Histopathological Studies. Animals 10, 1996; doi: 10.3390/ani10111996. 


\section{Amira L. Abd Allah}

Sinha, A. K. (1972):

Colorimetric assay of catalase. Anal Biochem, 47: 389-394.

Snedecor, G. and Cochran, W. (1979):

Statistical Method. 6th Ed. lowa State Collage U. S.A : 841.

Stathatos, N.,(2019):

Anatomy and physiology of the thyroid gland."The Thyroid and Its Diseases.Springer, Cham,.3-12.

Uchiyama, M. and Mihara, M. (1978):

Determination of malonaldehyde precursor in tissues by thiobarbituric acid test. Anal.Biochem. 86 (1) :271-8. doi: 10.1016/0003-2697(78)90342-1.

Vargas-Uricoechea, H. and Anilza B. (2017):

Thyroid dysfunction and heart failure: mechanisms and associations." Current heart failure reports $14(1)$ : 48-58.

Weckbeker, G. and Corey J.G. (1988):

Ribonucleotide reductase activity and growth of glutathione-depleted mouse leukaemia L1210 cells in vitro Cancer Lett., 40 , pp. 257-264. 
Egypt. J. of Nutrition and Health Vol. 16 No. 1 January (2021)

التأثير الوقائي للسبيرولينا ضد اضطرابات الغدة الدرقية الناجمة عن أحادي جلوتامـات

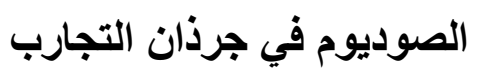

\section{أميرة لطفي عبد الرؤف عبد الله}

قسم التظذية وعلوم الأطعمة كلية الاقتصاد المنزلي- جامعة الأزهر

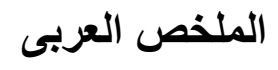

أحادي جلوتامات الصوديوم واحد من المضافات الغذائية الأكثر استخدامًا في العالم و التي يتم تناولها كجزء من الأطعمة المصنعة تجاريًا. أجريت هذه الدراسة للتحقق من التأثيرات الوقائية للسبيرولينا على اضطرابات الغدة الدرقية التي يسببها أحادي جلوتامات الصوديوم في الجرذان. نم استخدام ثلاثون من ذكور الجرذان البيضاء (170 ـ 10 جم). قسمت إلى 5 مجموعات متساوية تركت إحدها كمجموعة تحكم , مجموعة (2): تلقت عن من من طريق الفم جرعة يومية 60 ملجم/ كجم من وزن الجسم من احادي جلوتامات الصوديوم

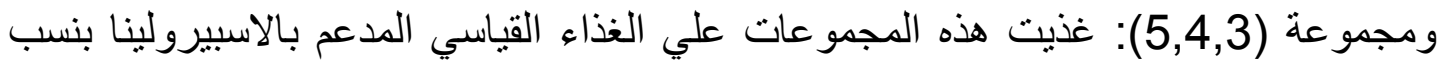
0,5 و 1 و2 \% وتلقت كذلك عن طريق الفم جرعة يومية 60ملجم/ كجم من وزن الجسم من احادي جلوتامات الصوديوم. تم فحص الغدة الدرقية باستخدام الدراسات البيولوجية و البيوكيميائية . وقد أظهر التركيب الكيميائي وتحليل HPLC للمركبات الفينولية أن الاسبيرولينا تعد مصدر جيد للبروتين و الكربوهيدرات والألياف والمعادن مثل اليود


التي تلقت الغذاء المدعم بالاسبيرولينا أشارت النتائج البيولوجية إلى حدوث انخفاض معنوي في النسبة المئوية للزيادة في وزن الجسم وتناول الغذاء. وأظهرت النتائج البيوكيميائية انخفاض كبير في هرمون TSH وزيادة في مستويات هرمون T3 و T4 في تللك المجموعات. أيضًا

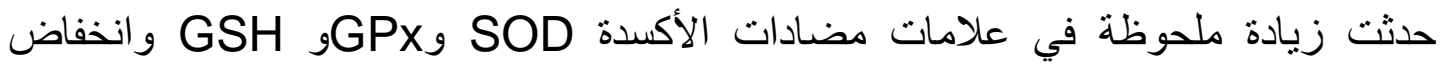
محتوى MDA في أنسجة الغدة الدرقية. وقد دعم الفحص النسيجي للغدة الدرقية هذه النتائج وكثف عن وجود آفة ملحوظة. لذللك، تكثف هذه الدراسة أن الاسبيرولينا قد تخفف من اضطر ابات الغدة الدرقية التي يسببها أحادي جلوتامات الصوديوم وتلعب دورًا مهمًا في تنظيم هرمونات الغدة الدرقية في الجرذان.

الكلمات المفتاحية: هرمونات الغدة الدرقية، الأحماض الفينولية ، الجلوناثيون بيروكسيديز ، الثيروكسين 